\title{
The Effectiveness of Red Ginger Compress Therapy (Zingiber officinale rosc. var. rubrum) on Elders with Joint Pain
}

\author{
Henik Tri Rahayu*, Ning Sri Rahayu and Sunardi Sunardi \\ Department of Physiotherapy, Faculty of Health Science, University of Muhammadiyah Malang, \\ Indonesia \\ Jl. Bendungan Sutami 188A, Kota Malang, Jawa Timur, 65145 \\ *Corresponding author: nshenik3r@gmail.com
}

\begin{abstract}
Background: Joint pain is common among elders in the community. Some of alternative pain management are applying red ginger compress and warm compresses therapy. Objective: This study aim was to determine the differences in the effectiveness of red ginger compress and warm compress therapy to reduce joint pain. Method: This study used Quasi-experimental with two group pre-posttest designs. The 20 elders with joint pain that fits the inclusion criteria from a Public Health Center in Malang was used as sample population. The simple random sampling was used to divide sample into 2 groups, intervention groups/red ginger compress therapy group $(n=10)$ and control group/warm compress group $(n=10)$. Data were analyzed using independent t-test. Result: The results showed that the two group indicate there were a decline of pain scale before and after intervention which red ginger compress can occupied declination of pain scale from average 6.5 to 2.5. of Independent $t$-test between red ginger compress and warm compresses sig value 0.037 ( $p<0.05$ ), indicate that there were a statistically significant different in effective reducing joint pain scale in elders. Conclusion: Red ginger has heat effect, anti-inflammatory and analgesic which can decrease joint paint more quickly than warm compress.
\end{abstract}

Keywords: Red Ginger Compress, Warm Compress, Joint Pain

\section{INTRODUCTION}

Indonesia has occupied fifth ranked worldwide the country with the highest number of elderly. Based on census on 2010, the number of elderly in Indonesia was 18.1 million people, and increase to 18.75 million on 2014 , then its estimated will be rising to 36 million people on 2025. The provinces based on the elderly spread were Yogyakarta, East Java and Middle Java which has $13.04 \%, 10.40 \%$ and $10.34 \%$ respectively (Kementrian Kesehatan RI, 2013).

Actually, there are many elders still can actively participate in societal activity, however because of aging process that force them to have some limitations. The physiological functions have decrease along with aging process, and in contrary the non-communicable disease has rising. Most of non-communicable disease happen in the elderly are hypertension, diabetes and joint pain (along with many causes) (Indonesian Directorate of Statistical Public Welfare, 2015). 
Joint pain is a common problem and the most cause of disability in elderly. The prevalence of joint pain among elders 45-64 years old was 30.3\% and among elders more than 65 years old was 49.7\% (Barbour, 2013). In addition, in Indonesia, the joint pain was one of 12 noncommunicable disease that have prevalence more than $24.7 \%$ (Badan Penelitian dan Pengembangan Kesehatan, 2013). Joint pain has many causes such as the reflection of many joint disease which rise from inflammation, cartilage degeneration, crystal deposition, infection and trauma (Baer, 2014). Therefore, joint pain mostly affects the mobilization, independently, participation in social activity, quality of life and become one of 10 causes of disability among elderly in developing countries (Hermsen et al., 2011).

Current treatment methods for patients with joint pain is aimed to improving mobility and joint function, and to optimize the quality of life by controlling risk factors, exercise, physiotherapy interventions, pharmacological therapy and surgery. Pharmacological therapy used include oral non-opioid analgesics, topical analgesics and Non-Steroid Anti-Inflammatory Drugs (NSAIDs). The use of NSAIDs is usually in the long-term way, so that it is sometimes cause many problems, such as gastrointestinal bleeding and kidney insufficiencies (Sudoyo, 2006). The most disadvantage is hepatotoxic (toxic to the liver) (Potter \& Perry, 2009). Besides, the non- pharmacological therapy to reduce joint pain are such as by cutaneous stimulation methods, relaxation and guided imagination, distraction, electrically transcutaneous nerve stimulation, and taking herbs medication. Gate-control theory states that stimulation of cutaneous nerve fibers sensory activate the transmission of A-beta which bigger and faster, this condition closes the "gate" thus lowering the pain transmission through the fiber $\mathrm{C}$ with a small diameter (Potter \& Perry, 2009). Stimulation of cutaneous such as warm and relaxation therapy showed a positive response to patients with osteoarthritis (Cantarini et al., 2007).

A warm compress is a method in the use of the local warm temperatures that can cause some physiological effects, including vasodilation, increase capillary permeability, improves cellular metabolism, relaxes muscles, and improves blood flow to an area. Besides, warm compresses can increase the temperature of tissue and local blood circulation, which can inhibit the metabolic products of inflammation such as prostaglandins, bradykinin, and histamine so that it can reduce pain. In addition, the physical changes in the collagen tissue will not only increase the metabolic activity, decrease muscle cramps, changes in neurological response, affecting musculoskeletal system activity, increasing muscle strength and endurance, but also the heat and warm feelings can increase comfort and reduce anxiety (Shim, 2014). Supported with other study of Fanada (2012), about the effectiveness of warm compresses in reducing the pain scale in elderly experiencing arthritic pain among Elderly in Social Institution Lotus Palembang. The study showed a significant difference between the pain scale before and after warm compress ( $\mathrm{p}$ value <0.05). Moreover, according to the Nursing Intervention Classification, warm compresses therapy is suggested in nursing interventions which aims to reduce pain, muscle spasms, or inflammatory (Bulechek et al, 2004). Besides, Susanti (2014) also reported that in her study there was a significant relationship between the effect of a warm compress of ginger against rheumatoid arthritis pain scale in the elderly (Wilcoxon sign rank test obtained $\mathrm{p}$ value $0.000(<0.05)$.

Not only warmth therapy, ginger solution is also stated has effective in lowering the pain. Ginger compress is a combination of warm and relaxation therapy that has a beneficial effect in patients with joint pain. The use of ginger in the form of compresses is safer than the use of ginger extract orally. The frequent and high doses of use of ginger extract orally can cause gastrointestinal disorders such as diarrhea (Therkleson, 2010). Ginger has the effect of pharmacological and physiological effects such as heat, anti-inflammation, antioxidant, 
antitumor, antimicrobial, anti- diabetic, anti-obesity, and anti-emetics (Rahmani et al., 2014).

In Indonesia, there are 3 kind of ginger including jahe gajah=Elephant ginger, red ginger and Emprit ginger. According to study of Hermani and Hayani (2001), red ginger has a starch substance about 52.9\%, essential oil (3.9\%) and alcohol-soluble extract $(9.93 \%)$ higher than other ginger, therefore the price of red ginger is the most expensive among them. Although red ginger has a high price, however the technical planting or cultivation is easy and the costs are relatively low. Ginger can be grown in the garden of house or just using a plant media in a poly bag or sack. Age of red ginger plants that can be harvested and used as medicine between 7-12 months, with the characteristics of the leaves has changing color from green to yellow and all the stem dried (Setyaningrum, 2013). The use of ginger topically can influence systemic absorption. The active ingredient in ginger are gingerol and shogaol which has a molecular weight of 150-190 Da, lipophilicity log P range of 3.5 and has medium solubility in water and oil that allows a good potential for penetration of the skin without causing irritation. Study on human skin using ginger extract prove that there was evidence of absorption which ginger extract is absorbed by the epithelial tissue and inhibit Cyclooxygenase (COX-2) (Mingetti et al., 2007). In addition, ginger also has a pharmacological effect such as hot and spicy taste where the heat can relieve pain, stiffness and muscle spasms as well as the occurrence of vasodilatation blood vessel.

Based on the report of Health Department of Malang City in 2014, Dinoyo Public Health Center is one of Public Health Centers in Malang with a high prevalence of joint pain with 3,462 visits, it also reported that the joint pain is one of the top ten most prevalent diseases in the elderly in that area. In addition, based on preliminary study using interview in ten elderly patients with joint pain indicates that it reduces their activity and interfere their daily work. Of the ten patients who complained of joint pain, three people take medicine from health centers and the rest take action as pain management such as massaging the painful area, applying an ointment and giving warm compresses. Unfortunately, when researcher asked about red ginger compress, they have never heard that compress using red ginger can reduce pain.

Red ginger compress and warm compresses are both non-pharmacological therapy which are effective, easy and safe to use to reduce pain. Theoretically red ginger has active ingredients that has similar effects as well as warm compress. Therefore, this study aims to determine the difference in effectiveness between Red Ginger Compress (Zingiber officinale ROSC. Var. Rubrum) and Warm compress to reduce Joint Pain in the Elders.

\section{METHOD}

This study used Quasi-experimental with two group pre-posttest design. This study was conduct on Posyandu Lansia (Public Health service for Elderly) in Sumbersari, Malang-East Java Indonesia on May 2016. The 20 elders with joint pain that fits the inclusion criteria from a Public Health Center in Malang was used as sample population. The inclusion criteria are elders who has joint pain with pain scale at least 4 in the time of measurement, having pain recurrent at least 3 times a week, and willing to be participant. Elders who taking analgesic, herbs and other pain killers were excluded in this study. The simple random sampling was used to divide samples into 2 groups, intervention group/red ginger compress therapy group $(\mathrm{n}=10)$ and control group/warm compress group $(n=10)$. The pain was measured using pain scale 0 to 10 . The pre-test of pain scale was measured before intervention and post-test was measure on day $7^{\text {th }}$ after intervention. The data collection was conduct on March, $16-30^{\text {th }} 2016$ after gaining some permission from department of Health in Malang City. The researcher meet participant in 
the Public Health center, explain about study and then informed consent were signed by participant when they agreed to be participant. The informed consent was consisting of anonymity, confidentiality and balancing of harms and benefits. The intervention was conducted in the participants' house, its takes 7 days' intervention a time a day every morning, evening or night. Participants in the intervention group were applied a warmth towel which was soaked on the solution of 20 grams fresh red ginger and $200 \mathrm{ml}$ hot water $\left(40^{\circ} \mathrm{C}\right.$ was measured using hot water thermometer) on the pain area for 20 minutes. While in the control group, participants were applied a towel of warmth water $\left(40^{\circ} \mathrm{C}\right)$.

Then the data were analyzed using independent t-test, along with univariate analysis of demographics factors, homogeneity test (Levene's test) which sig.787 ( $\mathrm{p}>0.05)$ indicate that data are homogeny and the normality test (Shapiro-Wilk) which red ginger group has sig.0.391 $(\mathrm{p}>0.05)$ and control group has sig. $0.328(\mathrm{p}>0.05)$ indicate that the data were normally distributed.

\section{RESULT AND DISCUSSION}

The participants were in the age $48-72$ years old with mean 58 years and most of them are woman $(65 \%)$. The figures of pain scale form baseline, after intervention and the comparison between before and after intervention for each group were showed in the Figure below:

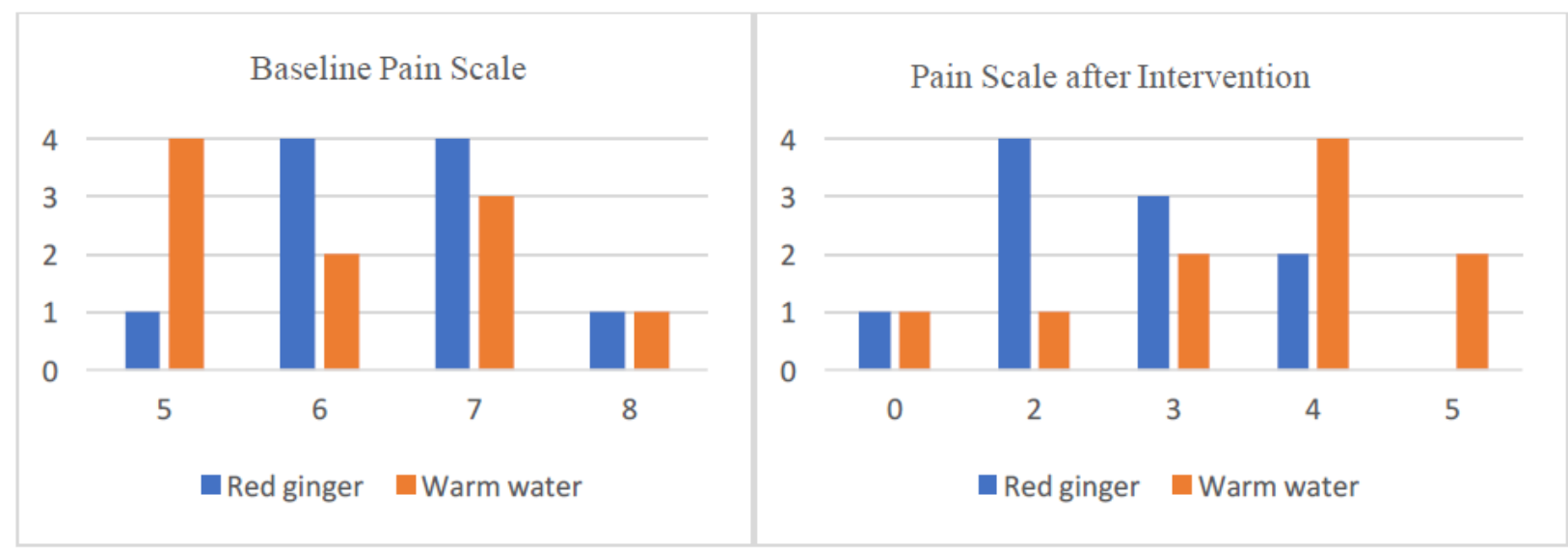

Figure 1 The baseline pain scale among two intervention and pain scale after two intervention

Based on the Figure 1, the baseline pain scale of red ginger group was mostly on scale 6 and 7 (mean 6.5), while in the control group was on scale 5 to 7 (mean 6.1). From the two groups, joint pain was felt when they waking up, going up and down stairs, start walking and carrying heavy objects. Experiences joint pain were caused by work or excessive activities, considering the majority of jobs in both groups were merchants (food stall), where such work has an intensity sit or stand for a long time. According to Amien (2013) the most frequent causes of joint pain are arthritis, past trauma, repeated load on the joint motion, wrong posture, aging process and immobilization for a long time.

Pain is a subjective perception which influenced by physiological, social, spiritual, psychological and cultural issues. Therefore, experience of pain is varied of each individual. The factors that influence of pain include age, weakness, neurological function, attention, previous experience, spiritual factors, anxiety, coping techniques and the sense of pain (Potter 
\& Perry, 2009). In this study, the age of respondents was in the range of 48 to 72 years old (mean age of 58 years), it indicates that someone will increase their pain scale along with age. According to the Statistics Directorate of Public Welfare (2015) along with the increasing of age there were physiological function decreases, so that elderly have a higher risk of experiencing pain which resulted from some pathological conditions. One of the functional decrease was on the musculoskeletal system where there is a change in the composition and number of the cartilage and the water soluble which can affect the joint loading that can cause joint pain and cartilage deformity (Masumeci et al., 2015).

Besides, gender can also affect a person's pain scale. Since mostly participants in this study were woman, so most of them have higher pain scale. As suggested from Rousseau and Goottlieb (2004), joint pain is more common in older women and it is often seen when women have undergone menopause. Women who are postmenopausal and going to be an elder, there were a period that estrogen is decline, which causing an imbalance of osteoblasts and osteoclasts activity that resulting the decreases of bone mass, causing bones thinner, hollow, stiffness and flaking joint cartilage then resulting a joint pain. In addition, according to Musumeci et al. (2015) the condition in woman compared to men, the differences were in bone and ligament structure, such as strength and alignment, ligament weakness or declining of cartilage volume.

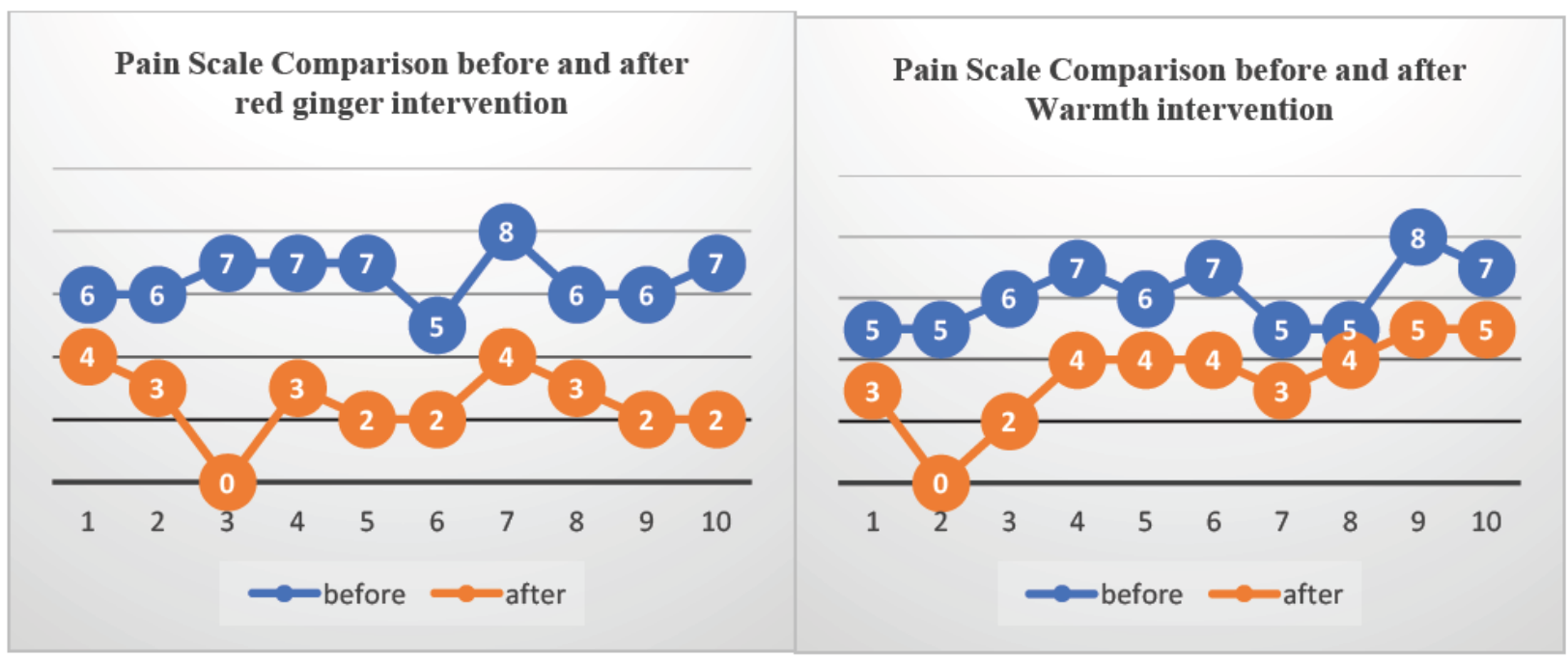

Figure 2 The comparison of pain scale before and after intervention

The Independent t-test showed that there were a significant statistically difference in effectiveness between Red ginger compress therapy and warmth compress therapy in reducing joint pain among sample (elders), sig. $0.037(\mathrm{p}<0.05)$.

Based on Figure 2, the pain scale after intervention of red ginger group was mostly on scale 2 and 3 (mean 2.5), while in the control group was on scale 4 to 5 (mean 3.4). In addition, from the Figure 3, it also indicates that among two groups, there were a decreasing of pain scale but the rate of pain scale declining was higher in the red ginger group (mean of rate $=4$, rather than 2.7 in the control group). Since red ginger compress is a combination of warm and relaxation therapy, it is beneficial in patients with joint pain. Moreover, red ginger has higher containing of oil and oleoresin rather than other types, so it is suitable for herbs medicine. Besides, ginger has a pharmacological and physiological effects such as the effects of heat, antiinflammation, analgesic, antioxidant, antitumor, antimicrobial, anti-diabetic, anti-obesity, anti- 
emetics (Rahmani et al., 2014). The use of ginger topically can influence the systemic absorption. Ginger extract is absorbed by the epithelial tissue that inhibit Cyclooxygenase (COX-2) (Mingetti et al., 2007). Moreover, ginger also has a pharmacological effect from its hot taste and spicy where the heat can relieve pain, stiffness and muscle spasms as well as the occurrence of vasodilatation blood vessel. Since it has many ingredients that affect the systemic, the heat resulting from its ingredients is longer than warm water compress so that the effect in reducing pain scale was more effective than warm water.

There were some limitations of this study. The instruments used on a warm compress group was a rubber bag filled with $50-60^{\circ} \mathrm{C}$ which applied for 20 minutes. Heat on the rubber bag cannot last up to 20 minutes, so it takes more than a rubber bag for one treatment. Whereas in the group of red ginger compress using media towel, we need maintain the heat so that the therapeutic effect of warmth compress reached. Besides, the number of samples in this study were only 20, which may cannot be generalized. Finally, there were a different in time intervention because of fits in the participant's leisure time, since there were many factors that affect a decrease in pain due to environment, psychological and physical conditions.

\section{CONCLUSION}

Based on this study result, red ginger compress therapy was more effective in reducing the joint pain scale among elders than only use a warm water compress. Therefore, it can be considered as an alternative of joint pain management in elders which easily, cheaper and beneficently. However, it still need further research knowing the details of side effects and fix effective and safely doses of using ginger as alternative medicine.

\section{REFERENCES}

Baer, A. (2014). The Approach to The Painful Joint. Retrieved from http://www.emedicine.medscape.com/article/3360540-overview.

Barbour, K., Helmick, C., Theis, K., et al. (2013). Prevalence of doctor-diagnosed arthritis and arthritis-attributable activity limitation — United States, 2010-2012. Morb Mortal Wkly Rep, 62(44), 869-873.

Cantarini, L., Leo, G., Giannitti, C., et al. (2007). Therapeutic effect of spa therapy and short wave therapy in knee osteoarthritis: A randomized, single blind, controlled trial. Rheumatology International, 27, 523-529.

Fanada, M. (2012). Pengaruh Kompres Hangat Dalam Menurunkan Skala Nyeri Pada Lansia Yang Mengalami Nyeri Rematik di Panti Sosial Tresna Werdha Teratai Palembang. Naskah Publikasi : Balai Diklat Provinsi Sumatra Selatan

Hermsen, L., Leone, S., Windt, D., et al. (2011). Functional Outcome In Older Adults With Joint Pain And Comorbidity: Design Of A Prospective Cohort Study. Musculoskeletal Disorders 2011, 12:241.

Hernani \& Hayani, E. (2001). Identification of chemical components on red ginger (Zingiber officinale var. Rubrum) by GC-MS. Proc. International Seminar on natural products chemistry and utilization of natural resources. UI-Unesco, Jakarta: 501-505.

Irawan, A. (2014). Efektivitas "HTM MIX" (Heat Therapy Massage MIX) terhadap Penurunan Tingkat Nyri Punggung Pada Pekerja kuli Panggul di UD. Soponyono Banyuwangi. Bachelor thesis. Unpublised: Universitas Muhammadiyah Malang.

Lozada, C. J. (2015). Osteoarthritis: Practice Essentials, Background, Anatomy. 
http://emedicine.medscape.com/article/330487-overview. Online access on January $06^{\text {th }}$ 2016.

Mingetti, P., Sosa, S., Cilurzo, F., Casiraghi, A et al. (2007). Evaluation Of The Topical AntiInflammatory Activity Of Ginger Dry Extracts From Solutions And Plasters. Planta Med. 2007 Dec;73(15):1525-30.

Musumeci, G., Aiello, F., Szychlinska, M., Rosa, M. et al. (2015). Osteoarthritis in the XXIst Century: Risk Factors and Behaviours that Influence Disease Onset and Progression. International Journal of Molecular Sciences, 16, 6093-6112.

Muttaqin, A. (2011) . Buku Ajar Asuhan Keperawatan Klien dengan Gangguan Sistem Persarafan. Jakarta: Salemba Medika. (2008). Buku Ajar Asuhan Keperawatan Klien Gangguan Sistem Muskuloskeletal. Jakarta: EGC.

Neogi, T. (2013). The Epidemiology and Impact of Pain in Osteoarthritis. Osteoarthritis Cartilage. 21(9): 1145-1153.

Rahmani, A. H., Shabrmi, F., Aly, S. (2014). Active Ingredients of Ginger as Potential Candidates in The Prevention and Treatment of Diseases Via Modulation of Biological Activities. Int. J Physiol Pathophysiol Pharmacol 2014;6(2):125-136.

Rusnoto. (2015). Pemberian Kompres Hangat Memakai Jahe Untuk Meringankan Skala Nyeri Pada Pasien Asam Urat Di Desa Kedungwungu Kecamatan Tegowanu Kabupaten Grobogan. Naskah Publikasi: STIKES Muhammadiyah Kudus, Jawa Tengah

The Effects of Wet Heat and Dry Heat on The Gait and Feet of Healthy Adults. The Society of Physical Therapy Science. 26. 183-185.

Supriyanto. (2012). Perbandingan Kandungan Minyak Atsiri Antara Jahe Segar dan Jahe Kering. Naskah Publikasi: Universitas Diponegoro.

Susanti, D. (2014). Pengaruh Kompres Hangat Jahe Tergadap Penurunan Skala Nyeri Artritis Rhematoid Pada Lansia di PSTW Kasih Sayang Ibu Batu Sangkar. Naskah Publikasi: Universitas Muhammadiyah Sumatra Barat.

Stockslager, J \& Schaeffer, L. (2007). Buku Saku Asuhan Keperawatan Geriatrik. Jakarta: EGC. Swarjana, I. (2012). Metodelogi Penelitian Kesehatan. Yogyakarta: ANDI.

Therkleson, T. (2010). Ginger compress therapy for adults with Osteoarthritis. Journal of Advanced Nursing, 66(10), 2225-2233.

Therkleson, T. (2014). Topical ginger treatment with a compress or patch for Osteoarthritis symptoms. Journal of Holistic Nursing, 23(3), 173-183.

Wulan, R.A. (2015). Pengaruh Terapi Kompres Air Hangat Terhadap Penurunan Skala Nyeri Sendi pada Wanita Lanjut Usia di Panti Tresna Werdha Mulia Dharma Kabupaten Kubu Raya. Naskah Publikasi: Fakultas Kedokteran Universitas Tanjungpura, Pontianak. 